\title{
Biomarkers and Ultra Structural Evaluation of Marine Pollution by Polycyclic Aromatic Hydrocarbons
}

\author{
Nehad M. Abd El Moneam', Nabila E. Abd El Maguid1, Amany M. El-Sikaily², Marwa G. Zaki², \\ Mohamed A. Sheradah ${ }^{3 *}$ \\ ${ }^{1}$ Biochemistry and Zoology Department, Faculty of Science, Alexandria University, Alexandria, Egypt \\ ${ }^{2}$ Marine Pollution Research Lab., National Institute of Oceanography \& Fisheries, Alexandria, Egypt \\ ${ }^{3}$ Marine Biotechnology Lab., National Institute of Oceanography \& Fisheries, Alexandria, Egypt \\ Email: *niof.shreadah@gmail.com
}

How to cite this paper: El Moneam, N.M.A., El Maguid, N.E.A., El-Sikaily, A.M., Zaki, M.G. and Sheradah, M.A. (2016) Biomarkers and Ultra Structural Evaluation of Marine Pollution by Polycyclic Aromatic Hydrocarbons. Journal of Environmental Protection, 7, 1283-1304. http://dx.doi.org/10.4236/jep.2016.710113

Received: July 11, 2016

Accepted: September 19, 2016

Published: September 26, 2016

Copyright $\odot 2016$ by authors and Scientific Research Publishing Inc. This work is licensed under the Creative Commons Attribution International License (CC BY 4.0).

http://creativecommons.org/licenses/by/4.0/

\section{(c) (i) Open Access}

\begin{abstract}
The present study is endeavored to study the oxidative stress and antioxidant response as well as the ultrastructural change of both liver and muscle tissues of Siganus rivulatus collected from polluted region (El-Mex Bay) and control region (Marsa Matrouh) to identify the significance of biomarkers. The results revealed that, ElMex Bay was polluted by different types of chemicals including hydrocarbons comparing with the reference area (Matrouh area). Where, the concentration range of total hydrocarbons in sediment samples collected from Matrouh coast was 409.24 $521.26 \mathrm{ng} / \mathrm{g}$, dry weight, where as this range in sediment samples collected from El-MexBay was 4159.77 - $4589.81 \mathrm{ng} / \mathrm{g}$, dry weight. In this context, the induction of antioxidant systems in fish collected from polluted area in response to oxidative stress should be considered as a clear indication of the presence of pollution and environmental health degradation. Also, The increase in lipid peroxidation was a useful indicator of the pollution load in the present study. The results suggest that chemical pollution is capable of inducing morphological alteration in liver offish collected from polluted area. The present study indicated that ultra-structural changes serveas biomarker of stress in aquatic environment.
\end{abstract}

\section{Keywords}

Biomarkers, Ultra Structural Evaluation, Polycyclic Aromatic Hydrocarbons (PAHs)

\section{Introduction}

Environmental pollution has increased substantially in the last decades due to a great 
number of industrial, agricultural, commercial and domestic waste, effluents and emissions as well as hazardous substances. Aquatic pollution is the predominant form of pollution since the majority of chemical pollutants are entering to sea, rivers, lakes and wetlands [1]-[9]. Marine and coastal ecosystems are characterized by their complexity and their sensitivity to various inorganic and organic pollutants [10]-[18]. Because environmental contaminants can have a broad spectrum of sub lethal effects on organisms, so bioindicators are useful tools for assessing the presence and levels of chemical pollution. Such effects in organisms sensitive to contaminant exposures can be used as early warning signs for the degradation of the environment [19]. Polycyclic aromatic hydrocarbons (PAHs) are a class of organic compounds consisting of two or more fused aromatic rings. They are one of the major categories of pollutants entering the marine environment and finally accumulating in the sediments. Polycyclic aromatic hydrocarbons (PAHs) can accumulate in the tissues of aquatic animals and as such tissue concentrations of chemical pollutants can be of public health concern to both animals and humans [20]-[27]. They are formed by three main processes: diagenesis, petrogenesis, and pyrolysis [28]. Diagenesis and petrogenesis are typically naturally-occurring, where as pyrolysis can be the result of natural or anthropogenic events [29]. Diagenesis occurs in organic matter that has been deposited in soils or sediments [30]. Pollutants accumulated in tissues of fish may catalyze reactions that generate reactive oxygen species (ROS) which may lead to environmental oxidative stress. Indicators of oxidative stress include changes in antioxidant enzyme activity, damaged DNA bases, protein oxidation products, and lipid peroxidation products [31]. Disturbance of living processes at the molecular and subcellular levels of biological organization by xenobiotics can lead to cell injury, resulting in degenerative and neoplastic diseases in target organs. Therefore histopathological biomarkers have been proven to be useful indicators of toxicity in fish organs [32].

The removal of xenobiotics, and even some endogenous substances, from the cell is catalyzed by a number of different enzymes, so called phase I and II enzymes. Phase I enzymes are involved in xenobiotic biotransformation via the introduction of a polar moiety which rendersa lipophilic contaminant to more hydrophilic. The cytochrome P450 (CYP) family is the most well studied in fish, especially CYP1A. CYP1A serves to increase the solubility of hydrophobic molecules through a reduction reaction involving an oxygen molecule [33]. Examples of phase II enzymes commonly used in biomonitoring programs involving fish are glutathione S-transferase (GST) and UDP glucuronyl transferase (UDPGT) [34]. The activity of phase I enzymes can lead to an increase in ROS production or the generation of reactive redox cycling intermediates. Antioxidant enzymes facilitate the removal of these reactive chemical intermediates and resulting ROS molecules. The action ofCYP1A can result in the production of $\mathrm{O}_{2}{ }^{-}-$which in turn can be metabolized by superoxide dismutase (SOD) to $\mathrm{H}_{2} \mathrm{O}_{2}$. This hydrogen peroxide molecule can then be reduced to $\mathrm{H}_{2} \mathrm{O}$ and $\mathrm{O}_{2}$ by catalase (CAT) [35]. Hydroxyl radicals $\left(\mathrm{OH}^{*}\right)$ can form both $\mathrm{H}_{2} \mathrm{O}_{2}$ and $\mathrm{O}_{2}{ }^{-}$-via reactions with redox cycling metal ions, for example iron and copper. This highly potent hydroxyl radical can attack both 
protein and lipid molecules to form oxidative damage products.

Lipid damage can occur as a result of oxidative stress or a disruption in the balance between prooxidant and antioxidant factors. Reactive oxygen species are known to extract hydrogen atoms from unsaturated bonds thereby altering lipid structure or function [36].

Since fish species, Siganus rivulatus, is considered as a sentinel species for environmental monitoring, it was chosen to study the oxidative stress and antioxidant response as well as the ultra-structural change of both liver and muscle tissues of Siganus rivulatus collected from polluted region, i.e. El-Mex Bay and control region, i.e. Marsa Matrouh to identify the significance of biomarkers.

\section{Materials and Methods}

\subsection{Study Area}

Matrouh is located in the north-western Mediterranean coast of Egypt $290 \mathrm{~km}$ west of Alexandria. It is a protected area far from land-based sources of pollution. On the other hand, El-Mex Bay located west of Alexandria, is a semi-elliptical open basin, extends for about $15 \mathrm{~km}$ between El-agamy head land in the west and the western harbor to the east and from the coast to a depth line of about $15 \mathrm{~km}$. the bay has a mean depth of about 10 $\mathrm{m}$ and surface area of about $19.4 \mathrm{~km}^{2}$. El-Mex Bay is a highly polluted area, the major types of pollution sources are domestic sewage, industrial waste water, and agricultural run-off, through lake out lets, and river discharged and oil pollution. El-Mex Bay receives mixed agricultural run-off from lake Mariout through El-max pumping station and El-umumdrain, industrial water from chloro-alkali plant, tanneries and slaughterhouse, also, air borne particles from the fumes of adjacent industrial plants including a cement factory [5] [11] [37]-[46]. Petroleum product from Al-Alamien oil field and from Suez Mediterranean pipeline terminal (SUMED) also contaminate the bay [47].

\subsection{Sampling}

Sediment samples were collected during March 2009 from ten stations, distributed along El-Mex Bay of Alexandria and, ten stations distributed along Matrouh coast as shown in Figure 1(a) \& Figure 1(b), respectively. At the same time Fish species (Siganus rivulatus), which belong to "Siganidea" were collected from El-Mex Bay and also from Matrouh coast. About 100 fish of similar weight (30 - $40 \mathrm{~g})$ were collected from each area. Samples were dissected and their liver as well as, muscles was removed and prepared for electron microscopic studies. While the remaining liver and muscle tissue kept frozen at $-20^{\circ} \mathrm{C}$ until use. Fish liver samples were weighted to the nearest milligrams and their hepato-somatic index (HIS, liver weight/bodyweight $\times 100$ ) was calculated according to Jangaard et al. [48].

\subsection{Methodology}

\subsubsection{Morphological Study}

Morphological features of Siganus rivulatus collected from both areas, i.e. El-Mex Bay 


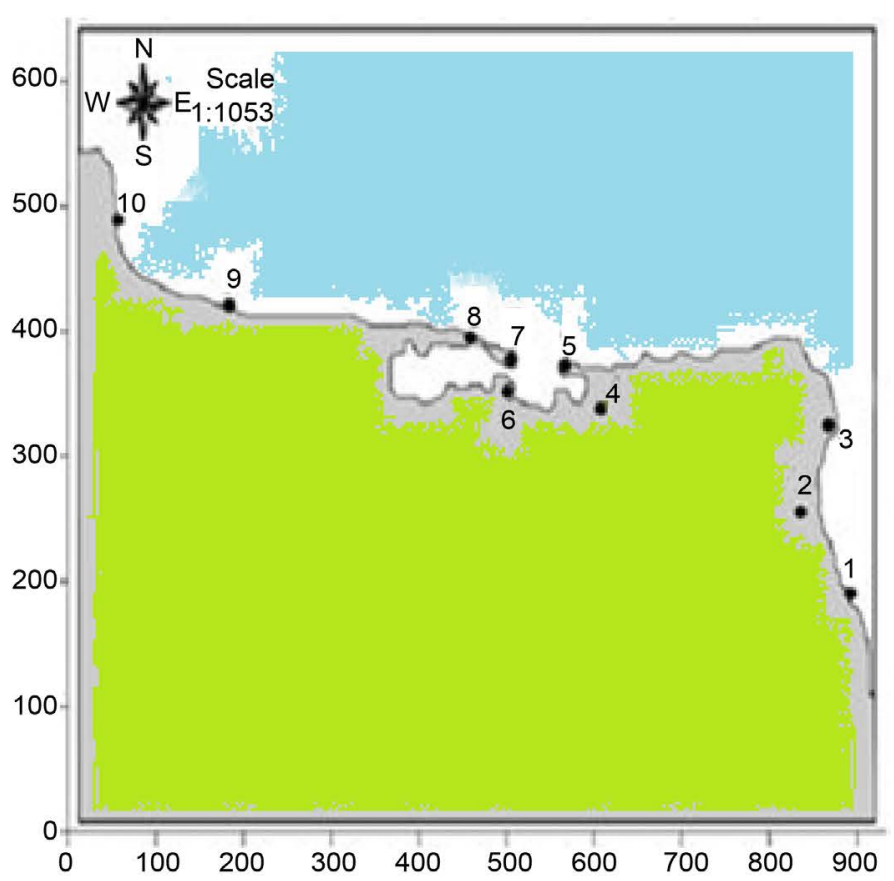

(a)

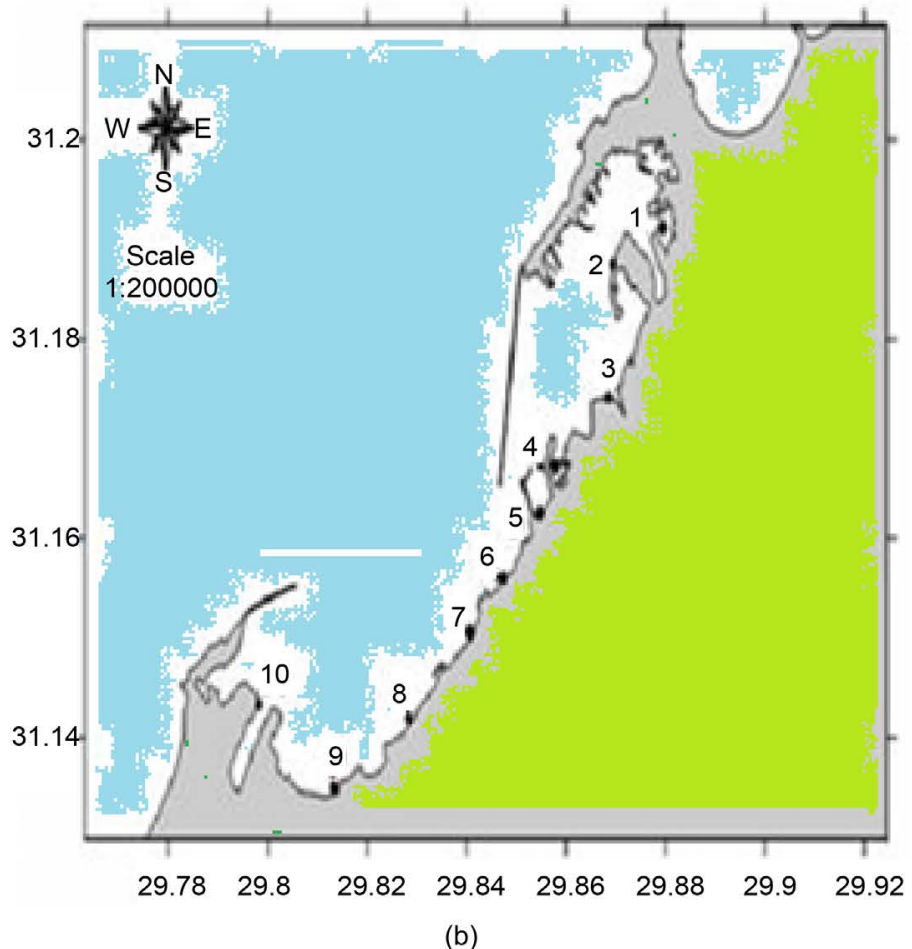

Figure 1. Location of sampling stations in the study area (a) Matrouh area and (b) El-Mex Bey area.

and Matrouh coast were determined. Both weight and length of Siganus rivulatus collected from both areas were taken and the hepato-somatic index (HIS = liver weight/ body weight $\times 100$ ) of fish was calculated. 


\subsubsection{Chemical Analysis}

Hydrocarbons have been determined in sediment and fish according to UNEP/IOC/ IAEA [49]. The samples were analyzed for aliphatic and aromatic hydrocarbons following these steps extraction, cleaning up and fractionation as well as their instrumental analysis followed by their analytical quality control. To control analytical reliability and assurance recovery efficiency as well as accuracy of the results, six analyses were conducted using hydrocarbon reference materials, HS-5 (sediment) provided by NRCIMB of Canada and SRM 2974 (freeze-dried mussel tissue) (Mytilus edulis) provided by NIST of USA As well as sediment samples of known hydrocarbon levels spiked with a mixture consisting of $2.0 \mu \mathrm{g}$ from each hydrocarbons were analyzed as above to validate the analytical method used in this study. The laboratory results showed recovery efficiency ranged from $90 \%-110 \%$ for HS-5, 85\% - 97\% for SRM-2974 and 94\% - 102\% for the spiked samples. All solvents were pesticide grade.

\subsubsection{Biochemical Analysis}

1) Preparation of tissue homogenate

Prior to dissection, liver tissue was perfused with a (phosphate buffer saline solution, pH 7.4 (PBS), containing $0.16 \mathrm{mg} / \mathrm{ml}$ heparin to remove any red blood cells. The tissue was homogenized in $5-10 \mathrm{ml}$ cold buffer $(100 \mathrm{mM}$ potassium phosphate, $\mathrm{pH}$ 7.0, containing $2 \mathrm{~m} \mathrm{MEDTA}$ )/g tissue, and then centrifuge at $10,000 \times \mathrm{g}$ for $15 \mathrm{~min}$. at $4^{\circ} \mathrm{C}$. The supernatant was removed for assay. The biodiagnostic Glutathione $S$-transferase assay kit (CAT. No. GT 2519 ) is used to measures total Glutathione $S$-Transferase activity by measuring the conjugation of 1-chloro-2, 4-dinitrobenzene (CDNB) with reduced glutathione. The conjugation is accompanied by an increase in absorbance at $340 \mathrm{~nm}$ [50]. Reduced Glutathione (GSH) concentration is determined by Biodiagnostic Gltathione reduced kit (CAT. No. GR 2511). The method based on the reduction of 5, 5' dithiobis (2-nitrobenzoic acid) (DTNB) with glutathione (GSH) to produce a yellow compound, the reduced chromogen directly proportional to GSH concentration and its absorbance can be measured at $405 \mathrm{~nm}$ [51]. The determination of lipid peroxidation is based on the reaction of malondialdehyde (break down product of lipid peroxides) with thiobarbituric acid (TBA), the resulting thiobarbituric acid reacting substances (TBARS) concentration, was determined by measuring the absorbance at $535 \mathrm{~nm}$ [52].

2) Microscopic study

Ultra thin sections $(50 \mathrm{~nm})$ were cut using LKB ultra tome with a glass knife, mounted on copper grids. Semi thin sections $(1 \mu \mathrm{m})$ were also cut from the sample blocks, stained with toluidine blue, and examined under a light microscope. Ultra thin sections were doublestained with freshly prepared uranyl acetate [53] for 20 minutes as well as leadcitrate for 5 minutes, and scoping grids was achieved by using JEOL 100CX transmission electron microscope of the Faculty of Science Alexandria University.

3) Statistical analysis:

This study was statistically analyzed using SPSS (version 10). A difference is considered as significant at $\mathrm{p}<0.05$. 


\section{Results and Discussion}

\subsection{Mophological Study}

The morphological study showed that the weight and length range for Siganus rivulatus collected from each area were relatively similar, but the hepatosomatic index for siganus rivulatus collected from El-Mex Bay was 2 fold more than those collected from Matrouh coast (Figure 2). Statistical analysis of data revealed a highly significant difference between the two investigated areas, i.e. El-Mex area and Matrouh area at $\mathrm{p}<0.05$.

\subsection{Chemical Analysis}

The results of the chemical analysis revealed that the concentration range of total hydrocarbons in sediment samples collected from Matrouh coast was 409.24 - $521.26 \mathrm{ng} /$ $\mathrm{g}$, dry weight, whereas the range in sediment samples collected from El-Mex Bay was 4159.77 - $4589.81 \mathrm{ng} / \mathrm{g}$, dry weight revealing the presence of high concentrations of total hydrocarbons in El-Mex Bay (tested area) compared to the reference area (Matrouh area). The statistical analysis of total hydrocarbons in sediment samples revealed a highly significant difference between the two areas at $\mathrm{p}<0.05$. The concentration of total hydrocarbons in sediment collected from El-Mex Bay (tested area) was 9.5 fold more than those of Matrouh coast (control area) as shown in Figure 3. The highest concentration was observed in sediments collected from station 7 (4589.81 ng/g dry weight) followed by stations $9,1,5$, while the lower concentrations were measured in samples collected from station 6 . These would suggested that hydrocarbons accumulated in Mediterranean sea sediments come from nearly human activities and fuel combustion emissions [5] [17] [25] [26] Kim et al. [54] demonstrated that the nature of the sediment influences the distribution and concentration of PAHs. Concentrations of PAHs in sediment were affected by chemical composition of the sediment such as organic matter and clay content. Sediments with high organic carbon content was characterized

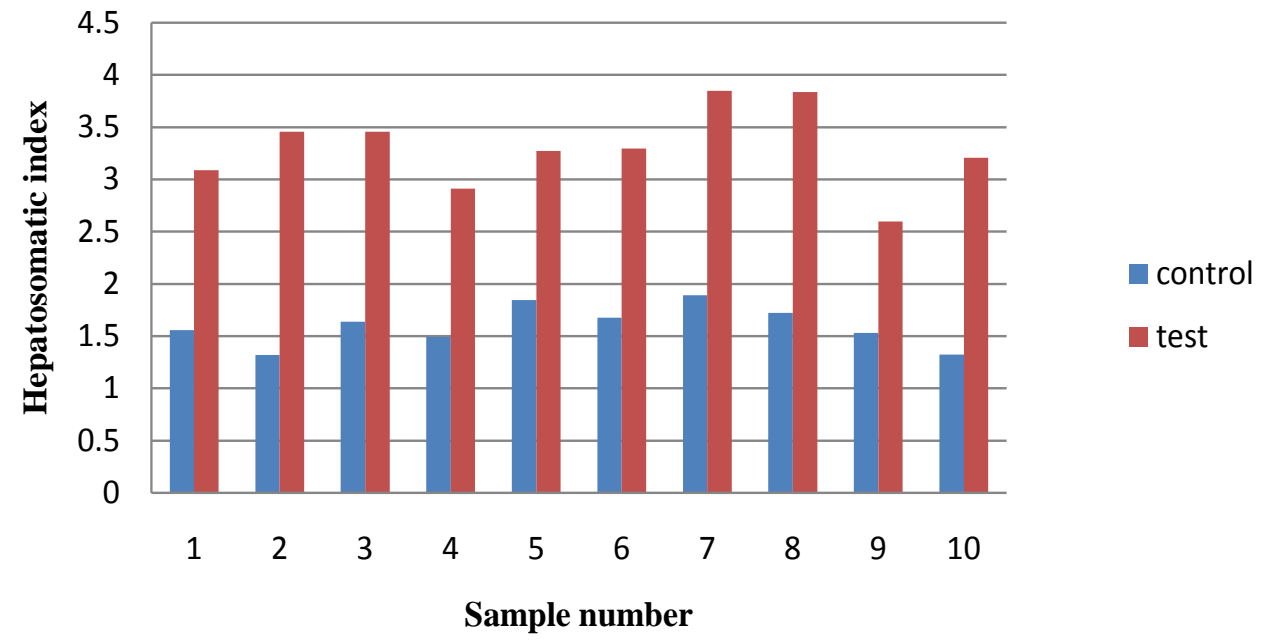

Figure 2. Hepatosomatic index of "Siganus rivulatus" collected from El-Mex Bay compared to Matrouh coast. 


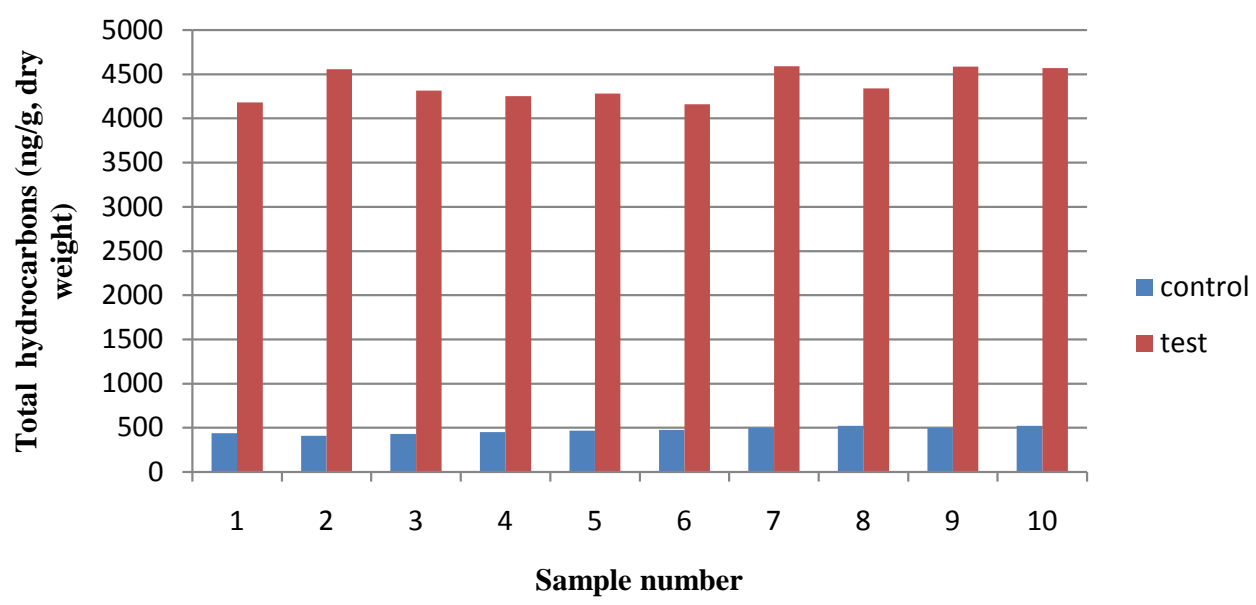

Figure 3. Total hydrocarbons concentration (ng/g, dry weight) of sediment samples Collected from El-Mex Bay compared to Matrouh coast.

by its high values of PAH's [55] [56]. Moreover, Simpson et al., [57] showed that the relationship between total PAHs in sediments and organic carbon was only significant for highly contaminated sites, containing PAHs concentration greater than $2000 \mathrm{ng} / \mathrm{g}$ dry weight. In the present study, all sediment samples collected from El-Mex Bay were characterized by its higher total organic carbon (TOC). The importance of sedimentary organic matter on the partitioning of PAHs in sediments has been well documented [58]. Leung et al. [19] found that the high partitioning of PAHs to sedimentary organic matter was mainly due to the significant aromatic fraction of the organic matter.

To determine the source of PAHs, the ratios of phenanthrene/anthracene, fluoranthrene/pyrene and Fluoranthene/Fluoranthene + Pyrene were used [59]-[61]. Where, phe/anth more than 10 indicated to petrogenic input. The ratio of flu/pyr less than 1 was attributed to petrogenic sources and when it is greater than 1 was obviously related to a pyrolytic origin. The present study revealed that, the ratio of phe/anth was less than 10 in both tested and control areas, suggesting that their PAH were pyrolytic-derived. All samples from the control area gave also flu/pyr ratio greater than 1 indicating to a pyrolytic origin of PAHs in this area. On contrast, sediments of El-Mex Bay area gave flu/pyr ratio less than 1 indicating a petrogenic origin of PAHs.

In Siganus rivulatus muscles the concentration range of total hydrocarbons collected from Matrouh coast was 104.72 - $219.18 \mathrm{ng} / \mathrm{g}$, dry weight, whereas, this range in Siganus rivulatus muscles collected from El-Mex Bay was $2239.52-3532.11 \mathrm{ng} / \mathrm{g}$, dry weight. There was a very high significantly difference between the two areas at $\mathrm{p}<0.05$. The concentration of total hydrocarbons in fish muscles collected from El-Mex Bay (tested area) was 16 fold more than those collected from Matrouh coast (control area) as shown in Figure 4. An elevation of PAHs in fish samples but it is still less than that found in sediments and higher than that present in the water column due to the increasing metabolism [25]-[27]. PAHs in the fish were mostly dominated by the high molecular weight PAHs (4 - 6 rings). Several studies [62] [63] have shown that fish preferentially bioaccumulate 4, 5 and 6 ringed PAHs rather than 2, 3 ringed PAHs. In 


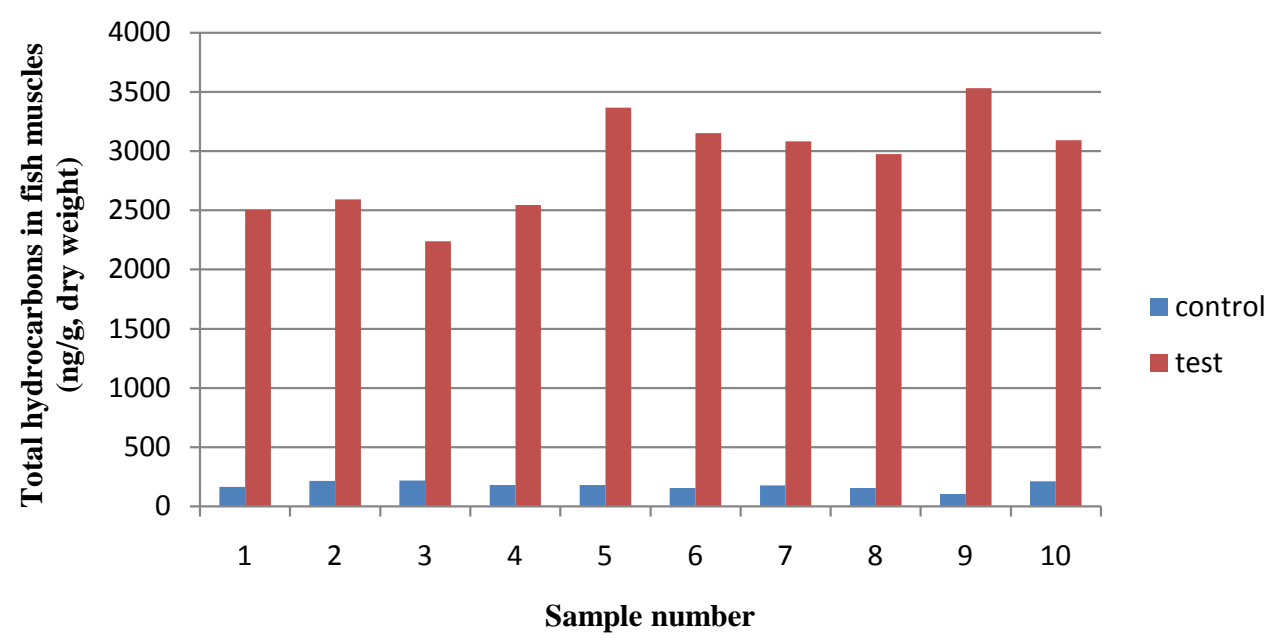

Figure 4. Total hydrocarbons concentration (ng/g, dry weight) of fish muscles collected from ElMex Bay) compared to Matrouh coast.

the present study, some samples of Matrouh had pr/ph ratio greater than 1 and other samples have undetected phytane this indicated that most PAHs of this control area get from zooplankton, while El-Mex Bay showed that pristine and phytane were present in all samples indicating the petroleum origin of PAHs in this area.

\subsection{Biochemical Analysis}

Contamination of water with industrial and agricultural pollutants influences the biochemical processes of aquatic organisms [64]. An effective monitoring system using biochemical markers has been established to demonstrate these xenobiotics in the environment [65]. On the other hand, the evaluation of oxidative stress is commonly used in monitoring programs based on measurements of catalyze (CAT), glutathione peroxidase (GPX) and superoxide dismutase (SOD) activities [66]-[68]. The generation of oxyradicals has a connection to the etiology of several human diseases and is probably the same for fish [69]. The statistical analysis of liver and muscle glutathione s-transferase revealed that there was a highly significant increase in liver and muscle glutathione s-transferase activity and glutathione concentration of Siganus rivulatus collected from El-Mex Bay than those collected from Matrouh coast at $\mathrm{p}<0.05$. Liver and muscle glutathione s-transferase activity of Siganus rivulatus collected from El-Mex Bay increased by $107.21 \%$ and $63.41 \%$, respectively, compared to those collected from Matrouh coast as shown in Figure 5 and Figure 6, respectively. Apart from the normal metabolism in a living organism; carcinogens (pesticides, heavy metals), infections (bacterial, parasitical, viral), radiation damage, and environmental stress factors cause an increase in free oxygen radicals and thus cause oxidative stress [70]. Recent findings show also that the pollution toxicity in an aquatic organism may be connected to increased production of reactive oxygen species (ROS) that leads to oxidative stress [71] [72]. In this respect, a number of studies confirmed the successful role of antioxidant enzymes and non-enzymatic antioxidant modulation in identifying environmental stress [73]. In addition, 


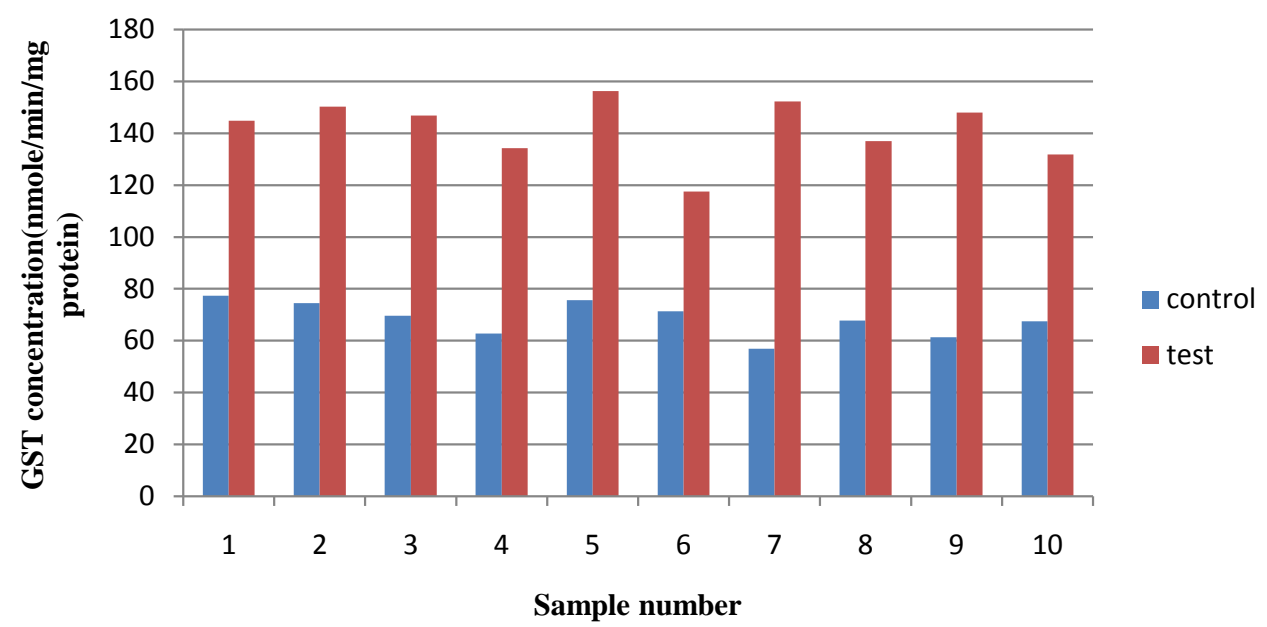

Figure 5. Liver glutathione s-transferase activity of "Siganus rivulatus" collected from El-Mex Bay compared to Matrouh coast.

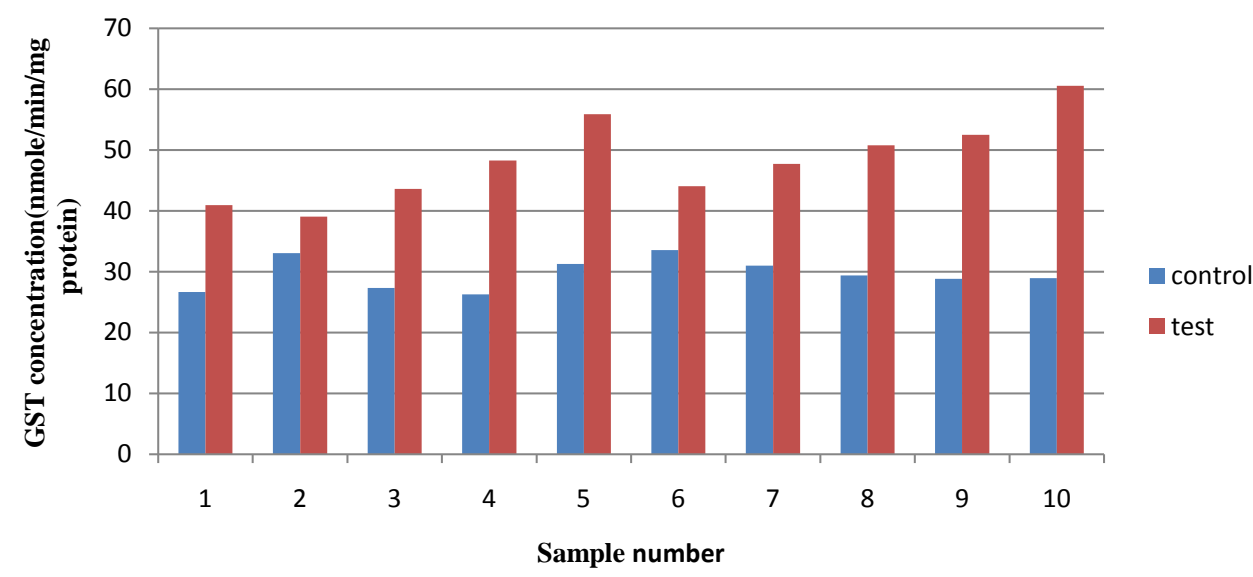

Figure 6. Muscle glutathione s-transferase activity of "Siganus rivulatus" collected from El-Mex Bay compared to Matrouh coast.

lipid peroxidation estimation in particular has also been found to have a high predictive importance as a biomarker of exposure [74]-[76]. Therefore, this study aimed to detect the oxidation stress response in liver and muscle of Siganus rivulatus collected from El-Mex Bay (tested area) and Matrouh (controlarea) to identify the significance of oxidative biomarkers as an early indicator of the health of marine ecosystem. Antioxidant enzymes were included in this study because of their inducibility under conditions of oxidative stress and their potential role in adaptation to pollutant-induced stress. An important liver biomarkers used for environmental pollution are glutathione S-transferase (GST) enzyme and glutathione in its reduced form (GSH) [77]. The presence of organic pollutants in fish muscle and their relation to specific biomarkers were also determined by Siroka et al., [78]. Where, the GST is an important intracellular enzyme of the second stage of xenobiotic metabolism. Its main function is to catalyze the conjugation of glutathione and electrophilic substances of exogenous origin that might be one of etiological factors of carcinogenesis and development of degenerative diseases [79]. It 
is used as a biochemical marker of aquatic environmental contamination with exogenous substances [80].

The liver and muscle tripeptide glutathione concentration of Siganus rivulatus collected from El-Mex Bay was increased by $73.63 \%$ and $77.54 \%$, respectively compared to its corresponding value collected from Matrouh coast (Figure 7 and Figure 8, respectively). The liver and muscle lipid peroxidation concentration for "Siganus rivulatus" collected from El-Mex Bay increased by $255 \%$ and $176 \%$, respectively, compared to those collected from Matrouh coast (Figure 9 and Figure 10, respectively). Moreover, measurements of lipid peroxidation which has been described as a biomarker for effect of pollution in several studies was also a useful indicator for the pollution load [71]. An elevation of MDA registered the oxidative stress due to the presence of contamination [79]. This study indicated the existence of a significant elevation in liver and muscle lipid peroxidation of "Siganus rivulatus" collected from El-Mex Bay compared to that

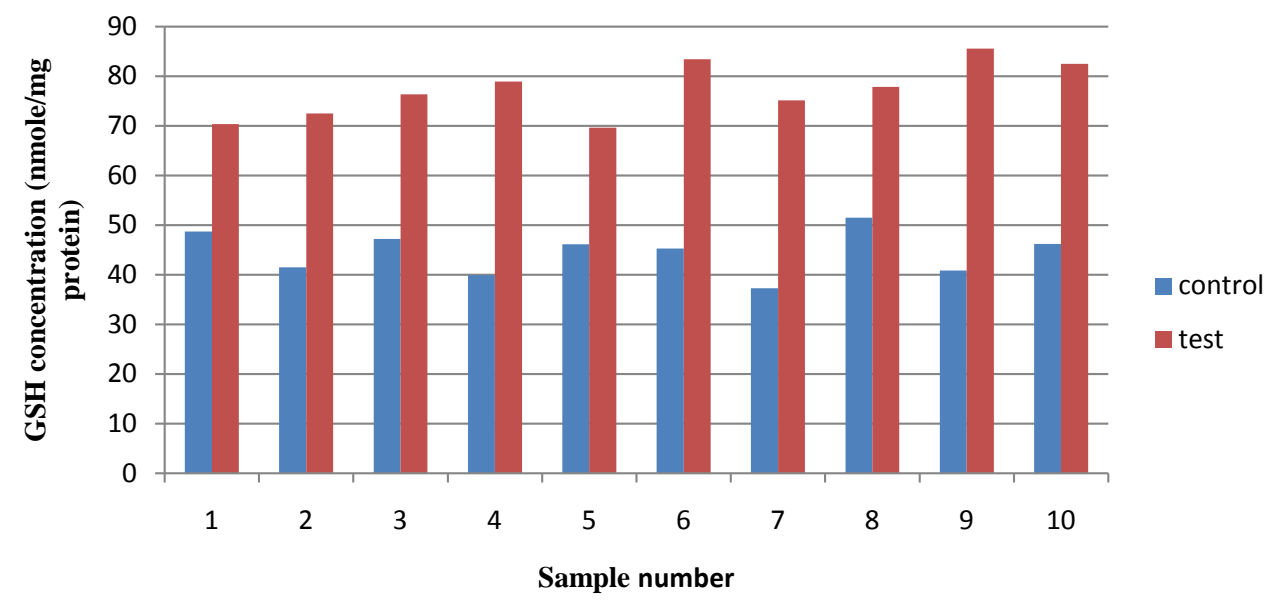

Figure 7. Liver glutathione reduced concentration of "Siganus rivulatus" collected from El-Mex Bay compared to Matrouh coast.

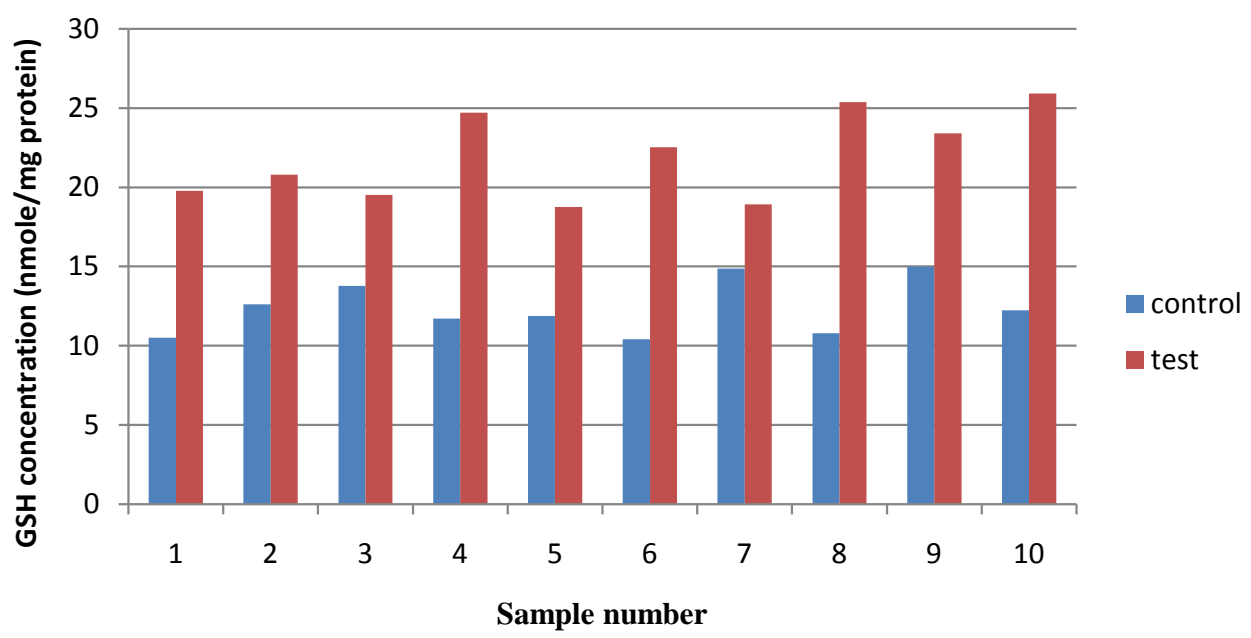

Figure 8. Muscle glutathione reduced concentration of "Siganus rivulatus" collected from El-Mex Bay compared to Matrouh coast. 


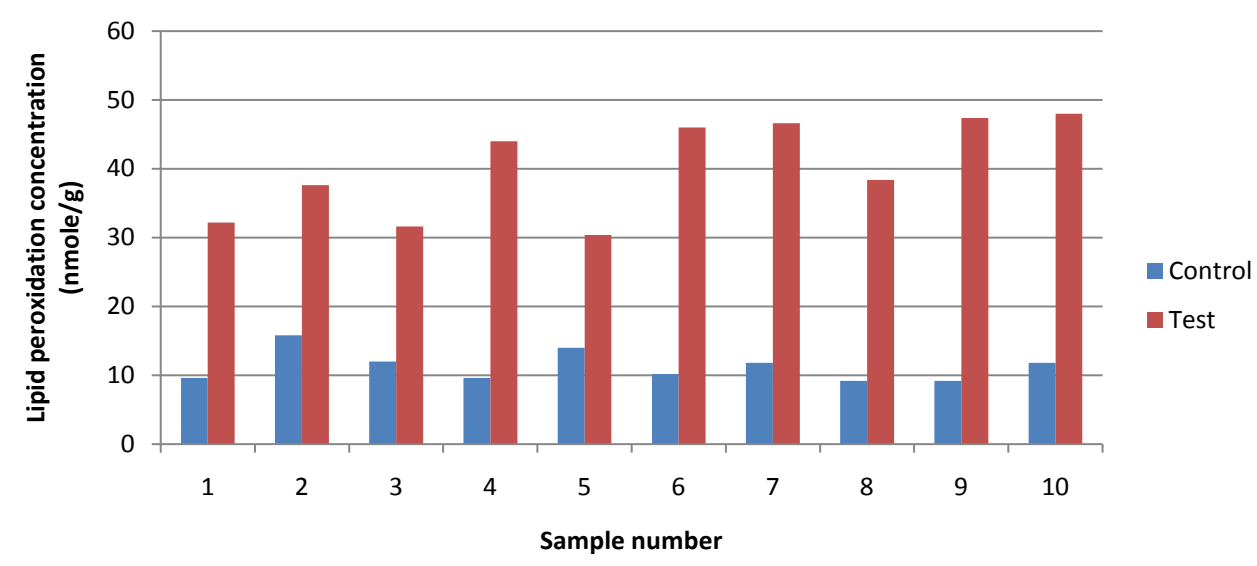

Figure 9. Liver lipid peroxidation concentration (nmole/g) of "Siganus rivulatus" collected from El-Mex Bay compared to Matrouh coast.

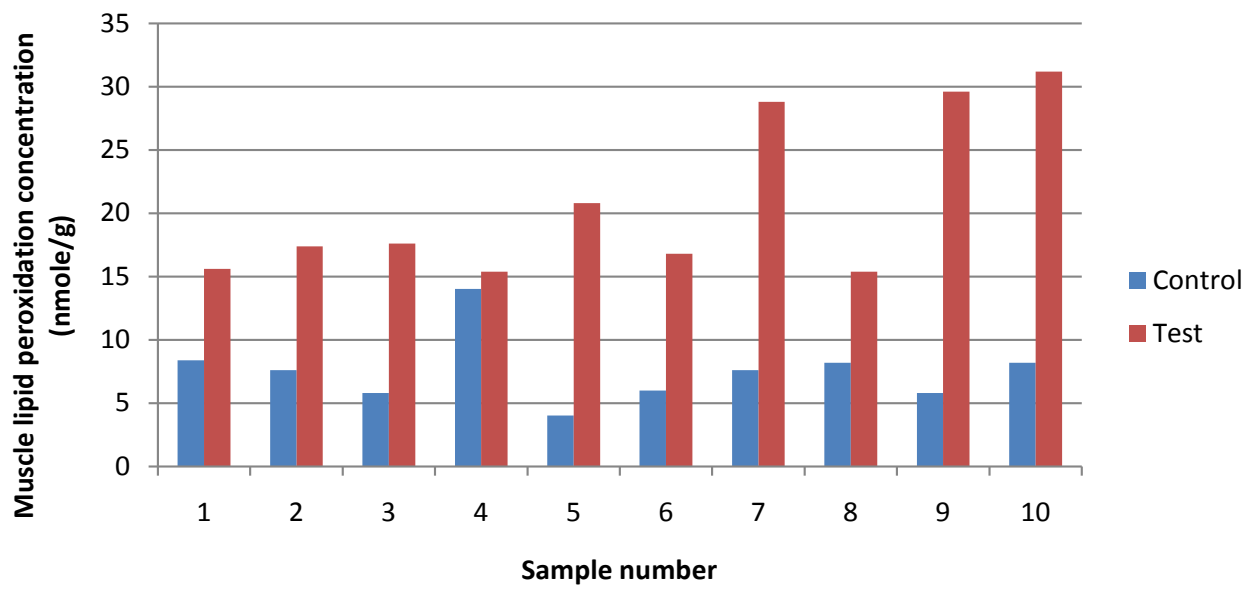

Figure 10. Muscle lipid peroxidation concentration (nmole/g) of "Siganus rivulatus" collected from El-Mex Bay compared to Matrouh coast.

collected from Matrouhcoast (Control area) as shown in Figure 9 and Figure 10. The apparent increase in lipid peroxidation may be attributed to the accumulation of the chemical pollutant in the organs under investigation indicating the existence of significant pollutant concentration in the fish liver and muscle of this area. Chemical pollutant catalyzes the formation of ROS capable to damage tissues such as DNA, proteins and lipids. [81]. The results of this study were in agreement with the work of Farombi et al., [82] who found that the level of MDA activity in the liver of Cat fish (Clarias gariepinus) collected from Ogun River (polluted area) was significantly elevated in all fish organs compared to the control fishes collected from the Agodi fish farm, the percentage increase in liver, kidney, gills and heart lipid peroxidation were $177 \%, 102 \%, 168 \%$ and $71 \%$ respectively compared to control.

\subsection{Microscopic Observations}

\subsubsection{Microscopic Observation of Hepatocytes}

Ultrastructurally, it was noticed that hepatocytes of liver of fish " $S$. rivulatus" collected 
from El-Mex Bay, showed hepatic alternations. The present study pointed out nuclear alternations in "Siganus rivulatus" hepatocytes collected from a polluted area (El-Mex Bay) using transmission electron microscopy, including shrunk nuclei, centric nucleoli, decreased heterochromatin and irregular nuclear envelopes (Figure 11). Ultrathin preparations (electron microscope) of liver of "S. rivulatus" collected from El-Mex Bay showed also indistinct membrane of mitochondria with some of which exhibited partial loss of cristea, other exhibited swelling. One of the main alterations in liver cells of " $S$. rivulatus" collected from El-Mex Bay in the present study was the increase in size and number of lipid droplets (Figure 11). An increase, on the other hand, in the number of lysosomes, peroxisome proliferations and extensive vacuolization were observed in "Siganus rivulatus" from El-Mex Bay. Moreover, accumulation of vacuoles resulted in the displacement of nuclei to the cell margin with pyknosis of the nuclei and increased number of melanomacrophage centers in hepatocytes of " $S$. rivulatus" from El-Mex Bay was observed (Figure 12). Most of such ultra-structural changes included fragmentation of rough endoplasmic reticulum. Irregular nuclear outline and induction of glycogenosomes and phospholipids are of nonspecific nature.

\subsubsection{Microscopic Observation of Muscle Fiber}

Electron microscopic examination of the muscle fibers of " $S$. rivulatus" collected from the control area showed their composition of sarcoplasm and longitudinal arrays of myofibrils. The center of each dark (A-band or actin) was occupied by a pale area

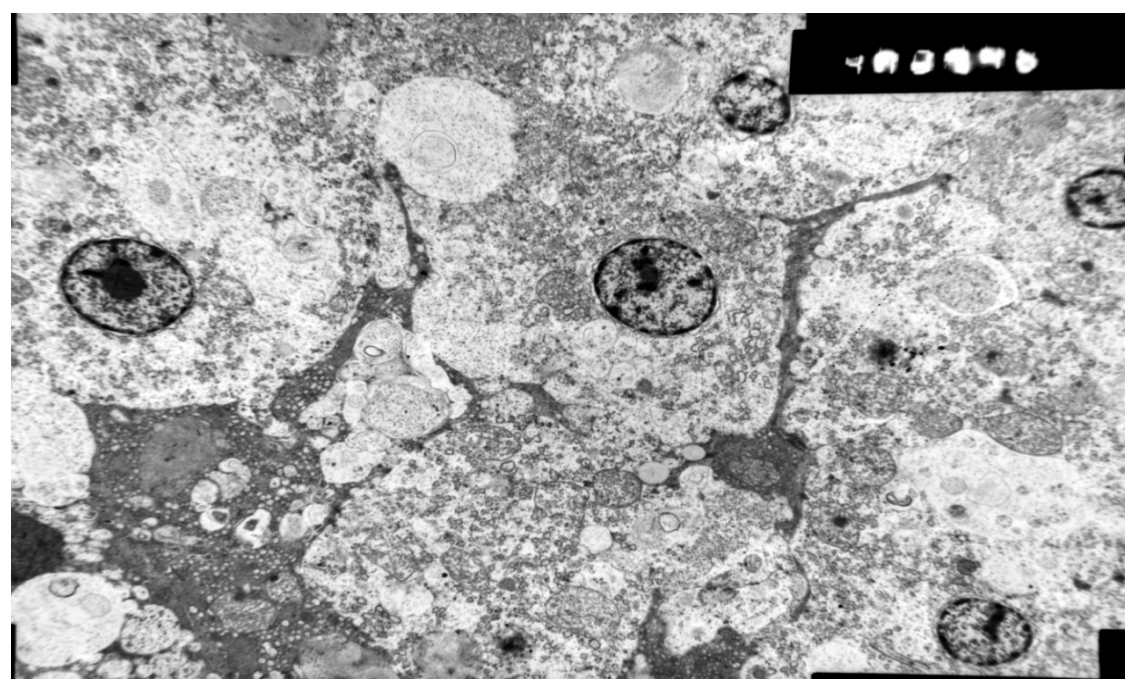

Figure 11. Electron micrograph. Liver section of "Siganus rivulatus" collected from Matrouh coast (control area). Showing, mononucleated hepatocytes interrupted by electron dense sinusoidal space (S), spherical central nucleus (N), with regular nuclear envelope ( $\mathrm{Ne}$ ), some nuclei showed centric large nucleoli (thin arrow), some nuclei revealed eccentric nucleoli (thick arrow), the hepatocyte nucleus possessed mostly regular nuclear envelope, small amount of condensed heterochromatin attached with the nucleolus $(\mathrm{Nu})$, rough endoplasmic reticulum (RER), spherical and avoid mitochondria (M) with short tubular cristae, small number of lipid droplets (L) [Glutaraldehyde fixed-OsO $\mathrm{O}_{4}$ post fixed-uranyl acetate-lead citrate stained preparation $\times 6000$ ]. 


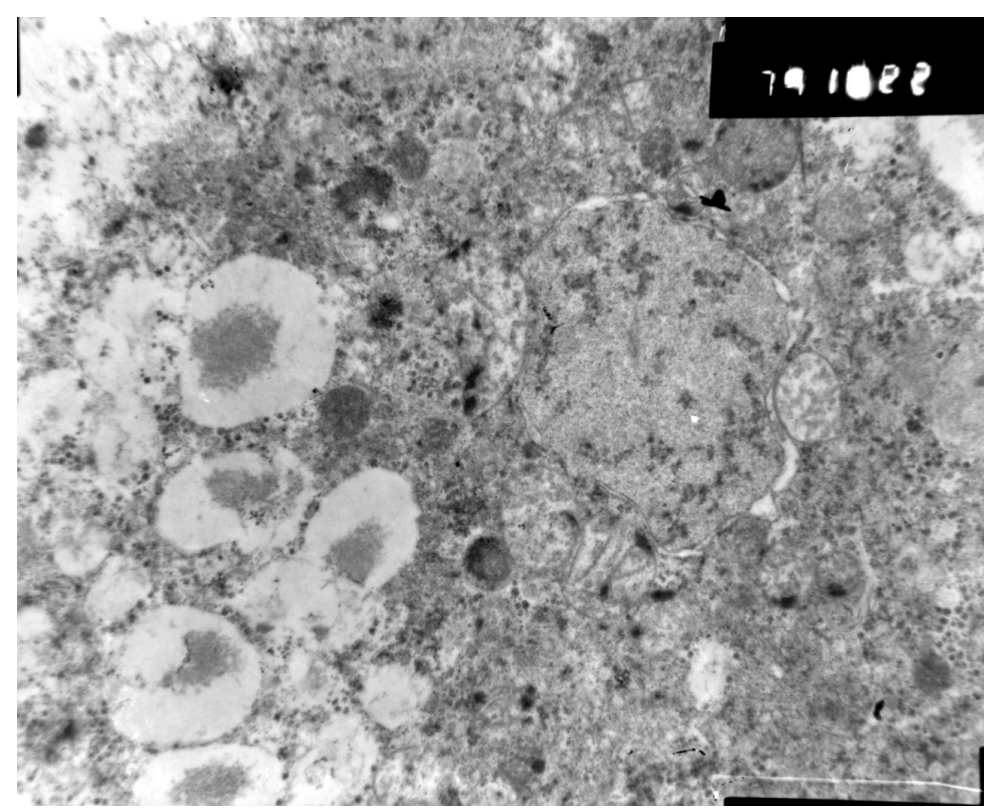

Figure 12. Electron micrograph, liver section of "Siganus rivulatus" collected from El-Mex Bay (tested area). Showing, altered nucleus (N) with irregular nuclear envelope $(\mathrm{Ne})$, most chromatin aggregate peripherally, large number of microbodies (Mi), numerous primary lysosomes (Ly), perixosomes (P), large empty vacuoles $(\mathrm{V})$ with flocculent materials and myline [Glutaraldehyde fixed-OsO $\mathrm{O}_{4}$ post fixed-uranyl acetate-lead citrate stained preparation $\times 10,500]$.

known as H-zone (Hensen's zone) which is bisected by an additional thin striation known as M-line (Mittelsheibe). A thin dark line, known as a Z-line (Zwischenscheibe) bisected the I-band which was relatively thick and distinguished by its density (Figure 13). Measurements based on electron microscopic preparations showed that there were insignificant differences in sacromere length, A-band, I-band and $\mathrm{H}$ zone in muscle fibres of "Siganus rivulatus" collected from control and test area at $\mathrm{p}<0.05$. Electron microscopic examination of the muscle of "Siganus rivulatus" collected from control area showed that the sarcoplasm is differentiated into peripheral sarcoplasm occupied a thin region and the nearest myofibrils, interfibrillar sarcoplasm filled the spaces between myofibrils and perinuclear sarcoplasm which is found at the pole of the nucleus. Moreover, the sarcoplasm contains non-myofibillar components including nuclei, mitochondria and sarcoplasmic reticulum, and cellular inclusions such as glycogen particles (Figure 13).

The nuclei of the "Siganus rivulatus" muscle collected from control area appeared just beneath the sarcolemma. They were oval or spindle shaped in appearance with predominant heterochromatin. Adjacent to the inner nuclear membrane, the heterochromatin appeared as dense aggregates surrounded by a regular nuclear envelope. The envelope appeared perforated by nuclear pores (Figure 13).

Electron microscopic preparations of the "Siganus rivulatus" muscle collected from tested area showed also that muscle fibers possessed highly altered nuclei, with large 
size nucleoli and irregular as well as disrupted nuclear envelope, with dilated nuclear pores (Figure 14). The analysis of the present study data using student $t$-test revealed that there is a highly significant decrease in the nuclear length in muscle cells of fish

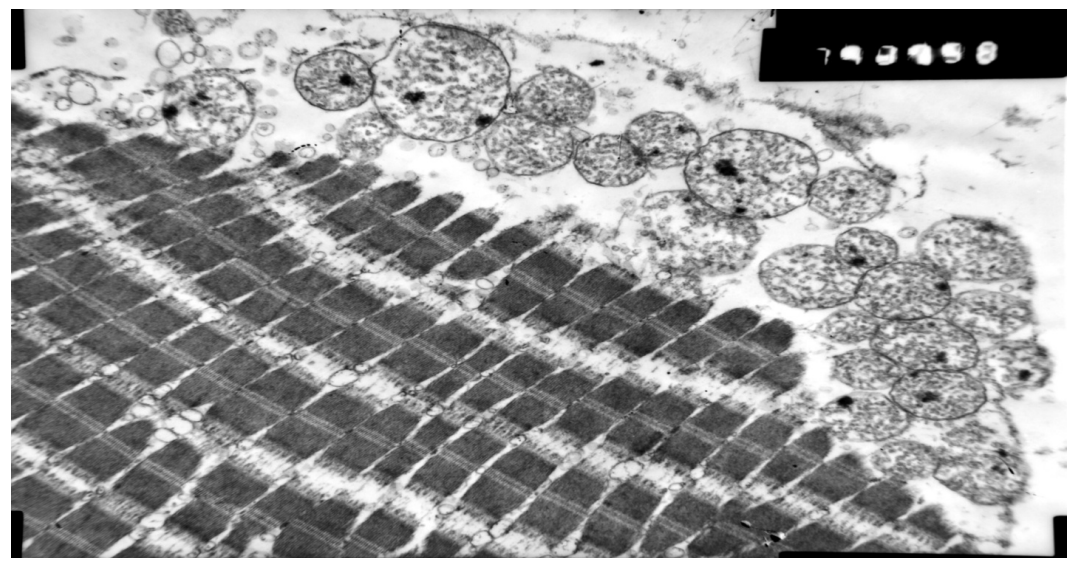

Figure 13. Electron micrograph. Longitudinal section of muscle of fish "Siganus rivulatus" collected from Matrouh coast (control area). Showing, regular striations, part of sarcolemma (Sl), numerous large size mitochondria (M) with distinct membrane, light matrix dense cristae. Arrow pointed at mitochondrial dense granules, sarcoplasmic reticulum ( $\mathrm{Sr}$ ). Note also, obvious isotropic band (I), $\mathrm{Z}$-line $(\mathrm{Z})$, anisotropic band $(\mathrm{A})$, less distinct $\mathrm{H}$-zone $(\mathrm{H})$ [Glutaraldehyde fixed$\mathrm{OsO}_{4}$ post fixed-uranyl acetate-lead citrate stained preparation $\left.\times 10,500\right]$.

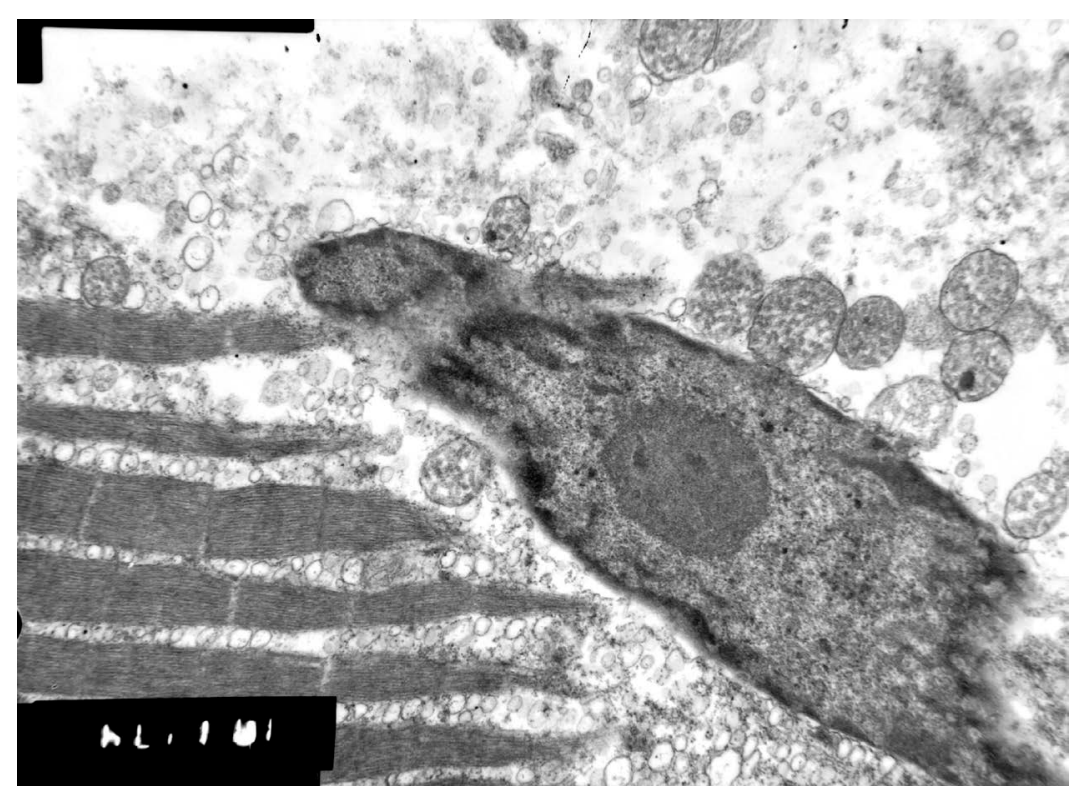

Figure 14. Electron micrograph. Longitudinal section of muscle of "Siganus rivulatus" collected from El-Mex Bay (tested area). Showing, highly altered nucleus $(\mathrm{N})$, with altered large size nucleolus $(\mathrm{Nu})$, with irregular disrupted nuclear envelope $(\mathrm{Ne})$, with dilated nuclear pores $(\mathrm{Np})$, small size mitochondria $(\mathrm{M})$ with dense matrix, sarcoplasmic reticulum (Sr), increase lipid droplets (L), lysis in the cytoplasm [Glutaraldehyde fixed-OsO ${ }_{4}$ postfixed-uranyl acetate-lead citrate stained preparation $\times 15,000]$. 
caught from the test area comparing to its corresponding length in control area. However, there was insignificant difference in the nuclei width between the two area at $\mathrm{p}<$ 0.05 .

Ultrastructural examination showed that the mitochondria of "Siganus rivulatus" muscle collected from the control area were oval in shape. They were clearly visible in the sarcoplasm adjacent to the nuclei and were also seen between the myofibrils. On the other hand, it was noticed that in "Siganus rivulatus" muscle collected from the test area, mitochondria appeared small in size with dense matrix. In these preparations the sub-sacrolemma mitochondria appeared disrupted and lysis in the cytoplasm (Figure 14). Data analysis using student $t$-test demonstrated that there is a highly significant decrease in the mitochondria length and width in the test area, comparing to that of control area at $\mathrm{p}<0.05$. In this context, the histopathological study confirmed the biochemical result where, the hepatocytes of liver of fish " $S$. rivulatus" collected from El-Mex Bay, showed hepatic alterations. It is suggested that this is due to increase concentration of different pollutants in El-Mex Bay [83]. This study also pointed out nuclear alterations in $S$. rivulatus hepatocytes collected from a polluted area using transmission electron microscope, including shrunk nuclei, centric nucleoli, decreased heterochromatin and irregular nuclear envelopes. It showed also mitochondrial indistinct membrane, some of which exhibited partial loss of cristea, other exhibited swelling. The mitochondrial degeneration may account for the impaired oxidative capability of hepatocytes in fish collected from the polluted location. According to the obtained biochemical results, the chemical pollutants induce lipid peroxidation and decrease the functional lipid content of tissues which can easily disturb the cellular metabolism and affect the ultra-structure. Thus, mitochondrial membranes damage affects their features; permeability, and selectivity. In consequence, they cannot regulate physiological processes and damaged mitochondria do not produce enough ATP, resulting in impair enzymatic detoxification within the exposed tissues [84]. These results are in agreement with results reported by Abdel-Moneim and Abdel-Mohsen in 2010, who found that catfish (Clariidae) hepatocytes collected from the polluted area showed accumulation of heterochromatin, enlarged nucleoli, and an extremely folded nuclear envelope. Tripathi and Shukla [85] Showed the mitochondrial degeneration may account for the impaired oxidative capability of hepatocytes in fish collected from the polluted area. Indeed, marked ultrastructural changes including, the presence of swollen mitochondria with loss of functional cristae due to exposed to methyl parathion. Electron microscopic examination of the $S$. rivulatus collected from test area showed also that muscle fibers (Figure 14) possessed highly altered nuclei with large size nucleoli, with irregular and disrupted nuclear envelop and mitochondria appeared small in size with dense matrix revealing that the histopathological biomarker of toxicity in fish organs is a useful indicator of environmental pollution.

\section{Conclusions}

The present study showed that El-Mex Bay area was polluted by different types of 
chemicals including hydrocarbons comparing with the reference area (Matrouh area). It was proven that the use of selected biochemical markers and chemical analysis has been a suitable to monitor the level of contamination of aquatic environment. The present study suggests that oxidative stress biomarkers, especially estimation of antioxidant systems in fish could provide a useful indicator of pollution of marine ecosystem. The induction of antioxidant systems in fish collected from polluted area in response to oxidative stress should be considered as a clear indication of the presence of pollution and environmental health degradation. The increase in lipid peroxidation revealed as a useful indicator of the pollution load in the present study. These results suggest also that chemical pollution is capable of inducing morphological alteration in liver of fish collected from polluted area. The present study indicated that ultrastructural changes serve as biomarker of stress in aquatic environment. When evaluating aquatic environmental pollution, it should always take into account a combination of several biochemical markers in any final assessment together of course with the results of chemical monitoring because only a combination of all this information will give the most objective picture of the status of the environmental monitoring.

\section{References}

[1] Wahby, S.D. and Shriadach, M.A. (1984) The Effect of Sewage Discharge on Some Chemical Characteristics of Seawater. 7 th Journees Etud Pollutions, Lvcerene, 11-13 October 1984, 81-90.

[2] Emara, H.I., Shriadah, M.A., Maoustafa, T.H. and El-Deek, M.S. (1995) Trace Metals-Nutrient Salts Relationship in Coastal Seawater of Alexandria. Proceedings of the 2 nd International Conference on the Mediterranean Coastal Environment, Tarragona, October 24-27 1995, 1457-1464.

[3] Shriadah, M.A. and Emara, H.I. (1991) The Distribution of Chromium, Copper, Cadmium, and Lead in Areas of Multi-Polluting Factors of Alexandria. International Proceeding of the Sympposium of Marine Chemistry in the Arab Region, Suez, April 1991, 30-50.

[4] Shriadah, M.A., Shobier, A.H. and Shreadah, M.A. (2013) Assessment of Arsenic and Vanadium Pollution in Surface Sediments of the Egyptian Mediterranean Coast. Journal of Environmental Technology and Management, 16, 82-101.

[5] Shriadah, M.A., Masoud, M., Khattab, A.M. and El Zokm, G. (2014) Impacts of Different Drains on the Seawater Quality of El-Mex Bay (Alexandria, Egypt). Journal of Ecology and the Natural Environment, 8, 287-303.

[6] Shriadah, M.A., Abdel Fattah, L. and Fahmy, M.A. (2015) Heavy Metals in Some Fish Species and Bivalves from the Mediterranean Coast of Egypt. Journal of Environmental Protection, 6, 1-9. http://dx.doi.org/10.4236/jep.2015.61001

[7] Shriadah, M.A., Shobier, A.H., Abdel Ghani, S., El-Zokm, G. and Said, T.O. (2015) Major Ions Anomalies and Contamination Status by Trace Metals in Sediments from Two Hot Spots along the Mediterranean Coast of Egypt. Environmental Monitoring and Assessment, 187, 280. http://dx.doi.org/10.1007/s10661-015-4420-y

[8] Shriadah, M.A., Masoud, M., Khattab, A.M. and El Zokm, G. (2015) Nutrient Fluxes and Sediments Composition in El Mex Bay and Surround Drains, Alexandria, Egypt. American Journal of Analytical Chemistry, 6, 513-527. http://dx.doi.org/10.4236/ajac.2015.66050

[9] Shriadah, M.A., Said, T.O., El-Sharkawi, F.M. and Mohamed, M.A. (2016) POPs in Sedi- 
ments of the Eastern and Western Coast of the Egyptian Mediterranean Sea: A Comparative Study. Development in Analytical Chemistry, 3, 1-11.

http://dx.doi.org/10.14355/dac.2016.03.001

[10] Shriadah, M.A., Mohmoud, T.H., El-Deek, M.S. and Emara, H.I. (1990) Study and Interpretation of the Recent State of Pollution in the Eastern Harbor of Alexandria. 1st International Environmental Science Conference, Sabha, 27-31 January 1990.

[11] Emara H.I. and Shriadah, M.A. (1991) Manganese, Iron, Cobalt, Nickel, and Zinc in the Eastern Harbor and El-Mex Bey Waters (Alexandria). International Proceedings of the Symposium of Marine Chemistry in the Arab Region, Suez, April 1991, 97-112.

[12] Shriadah, M.A. (1992) Trace Elements Concentration in Fish Samples from Alexandria Region. Bulletin High Institute of Public Health, 22, 437-444.

[13] Shriadah, M.A. and Emara, H.I. (1996) Heavy Metals (Iron, Manganese, Nickel, Cadmium, and Lead) in the Sediments from the Eastern Harbor and El-Mex Bay of Alexandria, Egypt. Proceedings of 6 th International Symposium: Environmental Protection Is a Must, Alexandria, 21-23 May 1996, 916-927.

[14] Abdel Fatah, L.M., Fahmy, M.A. and Shriadah, M.A. (2003) Zn, Cu, Cd, Pb and Hg in the Egyptian Coastal Sediments along the Mediterranean Sea. Association for Modeling and Simulation in Enterprises, 64, 55-69.

[15] Shakweer, L., Shriadah M.A., Fahmy, M.A. and Abdel Fattah, L. (2006) Distributions and Concentrations of Trace Elements along the Mediterranean Coastal Water of Egypt. Egyptian Journal of Aquatic Research, 32, 95-127.

[16] Abdel Ghani, S.A., Shobier, A.H., Said, T.O. and Shreadah, M.A. (2010) Organotin Compounds in Egyptian Mediterranean Sediments. Egyptian Journal of Aquatic Research, 36, 221-229.

[17] Shreadah, M.A., Said, T.O., Abdel Moniem, M.I., Fathallah, E.M.I. and Mahmoud, M.E. (2011) PAHsin Sediments along the Semi-Closed Areas of Alexandria, Egypt. Journal of Environmental Protection, 2, 700-709. http://dx.doi.org/10.4236/jep.2011.26081

[18] Shobier, A.H., Abdel Ghani, S.A. and Shreadah, M.A. (2011) Distribution of Total Mercury in Sediments of Four Semi-Enclosed Basins along the Mediterranean Coast of Alexandria. Egyptian Journal of Aquatic Research, 37, 1-11.

[19] Leung, H.M., Leung, A.O.W., Wang, H.S., Maa, K., Liang, Y., Ho, K.C., Cheung, K., Tohidi, F. and Yung, K.K.L. (2014) Assessment of Heavy Metals/Metalloid (As, Pb, Cd, Ni, Zn, Cr, $\mathrm{Cu}, \mathrm{Mn}$ ) Concentrations in Edible Fish Species Tissue in the Pearl River Delta (PRD), China. Marine Pollution Bulletin, 78, 235-245. http://dx.doi.org/10.1016/j.marpolbul.2013.10.028

[20] Shriadah, M.A. (1999) Oil Contamination along Oil Tanker Routes off the United Arab Emirates (The Arabian Gulf and The Gulf of Oman). Bulletin of Environmental Contamination and Toxicology, 63, 203-210. http://dx.doi.org/10.1007/s001289900967

[21] Shriadah, M.A. (1999) Petroleum Hydrocarbons along the Arabian Gulf Coast of the United Arab Emirates. Indian Journal of Marine Science, 28, 10-16.

[22] Shriadah, M.A. (2000) Levels and Distributions of Petroleum Hydrocarbons in the Coastal Waters and Sediments of the United Arab Emirates in the Arabian Gulf and the Gulf of Oman. Water, Air and Soil Pollution, 119, 247-256. http://dx.doi.org/10.1023/A:1005192523876

[23] Shriadah, M.A. (2000) Contamination by Petroleum Hydrocarbons in Two Semi-Enclosed Areas along the Arabian Gulf Coast of the United Arab Emirates. OEbalia, 26, 49-62.

[24] Shriadah, M.A. (2001) Petroleum Hydrocarbons Concentrations in Arabian Gulf Fish Tis- 
sues. Bulletin Environmental Contamination and Toxicology, 67, 560-567.

http://dx.doi.org/10.1007/s001280160

[25] El Deeb, M.K., Said, T.O., El Naggar, M.H. and Shriadah, M.A. (2007) An Assessment of Pollution Status of Abu Qir Bay with Polycycic Aromatic Hydrocarbons (PAHs) and Their Possible Origins. Proceedings of the 8 th International Conference on the Mediterranean Coastal Environment, Alexandria, 13-17 November 2007, 895-906.

[26] Shriadah, M.A., Said, T.O., Othman, I.M., Fathallah, E.M.I. and Mahmoud, M.E. (2012) Polychlorinated Biphenyls and Chlorinated Pesticides in Sediments along the Semi-Closed Areas of Alexandria, Egypt. Journal of Environmental Protection, 3, 141-149. http://dx.doi.org/10.4236/jep.2012.32018

[27] Shriadah, M.A., Said, T.O., Othman, I.M., Fathallah, E.M.I. and Mahmoud, M.E. (2014) Organochlorinesin Seawater from Egyptian Mediterranean Coast of Alexandria. Development in Analytical Chemistry, 1, 19-24.

[28] Alvarez, M.C., Franco, A., Perez-Dominguez, R. and Elliott, M. (2013) Sensitivity Analysis to Explore Responsiveness and Dynamic Range of Multi-Metric Fish-Based Indices for Assessing the Ecological Status of Estuaries and Lagoons. Hydrobiologia, 704, 347-362. http://dx.doi.org/10.1007/s10750-012-1314-7

[29] Duke, O.F. (2008) Source Determination of Polynuclear Aromatic Hydrocarbons in Water and Sediment of a Creek in the Niger Delta Region. African Journal of Biotechnology, 7, 282-285

[30] Cheng, Z., Man, Y.B., Nie, X.P. and Wong, M.H. (2013) Trophic Relationships and Health risk Assessments of Trace Metals in the Aquaculture Pond Ecosystem of Pearl River Delta, China. Chemosphere, 90, 2142-2148. http://dx.doi.org/10.1016/j.chemosphere.2012.11.017

[31] Sarkar, A., Ray, D., Shrivastava, A. and Sarker, S. (2006) Molecular Biomarkers: Their Significance and Application in Marine Pollution Monitoring. Ecotoxicology, 15, 333-340. http://dx.doi.org/10.1007/s10646-006-0069-1

[32] Mohamed, B., Bouraoui, Z., Ghedira, J., Clearandeau, C., Jebali, J. and Boussetta, H. (2009) Seasonal Variation of Oxidative Stress Biomarkers in Clams Ruditapes decussates Sampled from Tunisian Coastal Areas. Environmental Monitoring Assessment, 155, 119-128. http://dx.doi.org/10.1007/s10661-008-0422-3

[33] Luchmann, K., Toledo-Silva, G., Bainy, A. and Marques, M. (2007) Glutathione S-Transferase Cytosolic Isoform in the Pink-Shrimp, Farfantepenaeus brasiliensis, from Conceicao Lagoon, Santa Catarina Island, SC, Brazil. Environmental International, 33, 546-549. http://dx.doi.org/10.1016/j.envint.2006.11.005

[34] Halliwell, B. and Gutteridge, J. (1999) Free Radicals in Biology and Medicine. Oxford University Press, Oxford.

[35] Stephensen, E., Sturve, J. and Forlin, L. (2002) Effects of Redox Cycling Compounds on Glutathione Content and Activity of Glutathione-Related Enzymes in Rainbow Trout Liver. Comparative Biochemistry and Physiology Part C, 133, 435-442. http://dx.doi.org/10.1016/s1532-0456(02)00129-1

[36] Dusmant, M., Karmabeer, J., Navnath, M. and Tanaji, G. (2010) Assessment of Oxidative Stress Indices in a Marine Macro Brown Alga Padina tetrastromatica (Hauck) from Comparable Polluted Coastal Regions of the Arabian Sea. Journal of Environmental Sciences, 22, 1413-1418. http://dx.doi.org/10.1016/S1001-0742(09)60268-0

[37] Fahmy, M.A., Tayel, F.R. and Shriadah, M.A. (1995) Effect of Pollution on the Water Quality of Mex Bay and Dekhaila Harbor of Alexandria. 1 st International Conference on Present and Future Technology of Navigation and Marine Science of Mediterranean and the Red 
Sea, Alexandria, 29-31 October 1995.

[38] Shriadah, M.A. and Emara, H.I. (1992) Major Cations and Alkalinity in the Eastern Harbor and El-Mex Bey. Bulletin Faculty of Science, 32, 156-174.

[39] Shriadah, M.A. and Emara, H.I. (1992) Iron, Manganese, Nickel, Lead, and Cadmium in Fish and Crustacea from the Eastern Harbor and El-Mex Bay of Alexandria. Bulletin of High Institute of Public Health, 22, 515-525.

[40] Shriadah, M.A., Emara, H.I., Maoustafa, T.H. and El-Deek, M.S. (1992) Effects of Sewage and Industrial Wastes on the Chemical Characteristics of the Eastern harbor and El-Max Bay Waters of Alexandria, Egypt. Science of the Total Environment, 112, 773-784.

[41] Said, M.A., El-Deek, M.S., Mamoud, T.H. and Shriadah, M.A. (1994) Effect of Pollution on the Hydrochemical Characteristics of Different Water Types in El-Mex Bay Area West of Alexandria, Egypt. Acta Adriatica, 34, 9-19.

[42] Tayel, F.R., Fahmy, M.A. and Shriadah, M.A. (1996) Studies on the Physic Chemical Characteristics of Mex Bay and New Dekhaila Harbor Waters of Alexandria, Egypt. Bulletin National Institute of Oceanography \& Fisheries, 22, 1-18.

[43] Shriadah, M.A., Said, T.O., Younis, A.M. and Farag, R.S. (2006) Physico-Chemical Characteristics of the Semi-Closed Areas along the Mediterranean Coast of Alexandria, Egypt. Egyptian Journal of Aquatic Research, 32, 38-48.

[44] Shriadah, M.A., Said, T.O., Younis, A.M. and Farag, R.S. (2006) Speciation of Organotin Compounds in Sediments of Semi-Closed Areas along the Mediterranean Coast of Alexandria. Chemistry and Ecology, 22, 395-404. http://dx.doi.org/10.1080/02757540600917443

[45] Fathy, S.A., Abdel Hamid, F.F., Shreadah, M.A., Mohamed, L.A. and El-Gazar, M.G. (2012) Effect of Some Environmental Pollutants on Enzymatic and Total Antioxidant Activities in Tilapia Niloticus. Blue Biotechnology Journal (BB), 1, 433-443.

[46] Fathy, S.A., Abdel Hamid, F.F., Shreadah, M.A., Mohamed, L.A. and El-Gazar, M.G. (2012) Application of Principal Component Analysis for Developing Water Quality Index for Selected Coastal Areas of Alexandria Egypt. Recourses and Environment Journal, 2, 297-305.

[47] Sukumaran, P. and Das, A. (2004) Distribution and Abundance of Rotifers in Relation to Water Quality of Some Tropical Reservoirs. Indian Journal of Fisheries, 51, 295-301.

[48] Jangaard, P., Brockerhoff, H., Burgher, R. and Hoyle, R. (1967) Seasonal Changes in General Condition and Lipid Content of Cod from Inshore Waters. Journal of the Fisheries Research Board of Canada, 24, 607-612. http://dx.doi.org/10.1139/f67-052

[49] UNEP/IOC/IAEA (1991) Sampling of Selected Marine Organisms and Sample Preparation for the Analysis of Chlorinated Hydrocarbons. Reference Methods of Marine Pollution Studies No. 12, Revision 2, United Nations Environment Programme, Nairobi, 17.

[50] Habig, W.H., Pabst, M.J. and Jokoby, W.B. (1974) Glutathione 5-Transferases. The First Enzymatic Step in Mercapturic Acid Formation. Journal of Biological Chemistry, 249, 7130-7139.

[51] Beutler, E., Duron, O. and Kelly, B.M. (1963) Improved Method for the Determination of Blood Glutathione. Journal of Laboratory and Clinical Medicine, 61, 882-888.

[52] Buege, J. and Aust, S. (1978) Microsomal Lipid Peroxidation. Methods Enzymology, 52, 302-310. http://dx.doi.org/10.1016/S0076-6879(78)52032-6

[53] Reynolds, E. (1963) The Use of Lead Citrate at High pH as an Electron-Opaque Stain in Electron Microscopy. Journal of Cell Biology, 17, 208-212. http://dx.doi.org/10.1083/jcb.17.1.208

[54] Kim, G.B., Maruya, K.A., Lee, R.F., Lee, J.H., Koh, C.H. and Tanabe, S. (1999) Distribution 
and Sources of Polycyclic Aromatic Hydrocarbons in Sediments from Kyeonggi Bay, Korea. Marine Pollution Bulletin, 38, 7-15. http://dx.doi.org/10.1016/S0025-326X(99)80006-X

[55] Witt, G. (1995) Polycyclic Aromatic Hydrocarbons in Water and Sediment of the Baltic Sea. Marine Pollution Bulletin, 31, 237-248. http://dx.doi.org/10.1016/0025-326X(95)00174-L

[56] Yang, G.P. (2000) Polycyclic Aromatic Hydrocarbons in the Sediments of the South China Sea. Environmental Pollution, 108, 163-171. http://dx.doi.org/10.1016/S0269-7491(99)00245-6

[57] Simpson, C.D., Mosi, A.A., Cullen, W.R. and Reimer, K.J. (1998) Composition and Distribution of Polycyclic Aromatic Hydrocarbon Contamination in Surficial Marine Sediment from Kitimat Harbor Canada. Science of the Total Environment, 181, 265-278. http://dx.doi.org/10.1016/0048-9697(95)05026-4

[58] Salgueiro, L., Carballo, E., Falcón, M. and Gándara, J. (2009) Survey of Polycyclic Aromatic Hydrocarbons in Canned Bivalves and Investigation of Their Potential Sources. Food Research International, 42, 983-988. http://dx.doi.org/10.1016/j.foodres.2009.04.003

[59] Sicre, M.A., Marty, J.C., Saliot, A., Aparicio, A., Grimalt, J. and Al-Baiges, J. (1987) Aliphatic and Aromatic in Different Sized Aerosols over the Mediterranean Sea: Occurrence and Origin. Atmospheric Environment, 21, 2247-2259. http://dx.doi.org/10.1016/0004-6981(87)90356-8

[60] Soclo, H.H., Garrigues, P.H. and Ewald, M. (2000) Origin of Polycycilic Aromatic Hydrocarbons (PAHs) in Coastal Marine Sediments: Case Studies in Cotonou (Benin) and Aquitaine (France) Areas. Marine Pollution Bulletin, 40, 387-396. http://dx.doi.org/10.1016/S0025-326X(99)00200-3

[61] El Sikaily, A., Khaled, A., El Nemr, A., Said, T.O. and Abd-Allah, A.M.A. (2002) Determination of Hydrocarbons in Bivalves from the Egyptian Mediterranean Coast. Medcinal Marine Science, 312, 123-131.

[62] Nakata, H., Sakai, Y., Miyawaki, T. and Takemura, A. (2003) Bioaccumulation and Toxic Potencies of Polychlorinated Biphenyls and Polycyclic Aromatic Hydrocarbons in Tidal Flat and Coastal Ecosystems of the Ariake Sea, Japan. Environmental Science \& Technolo$g y, 37,3513-3521$. http://dx.doi.org/10.1021/es021083h

[63] Troisi, G., Bexton, S. and Robinson, I. (2006) Polyaromatic Hydrocarbon and PAH Metabolite Burdens in Oiled Common Guillemots (Uriaaalgae) Stranded on the East Coast of England (2001-2002). Environmental Science \& Technology, 40, 7938-7943. http://dx.doi.org/10.1021/es0601787

[64] Hylland, K., Tollefsen, K.E., Ruus, A., Jonsson, G., Sundt, R.C., Sanni, S., Utvik, T.I., Jangaard, P., Brockerhoff, H., Burgher, R. and Hoyle, R. (1967) Seasonal Changes in General Condition and Lipid Content of Cod from Inshore Waters. Journal of the Fisheries Research Board of Canada, 24, 607-612. http://dx.doi.org/10.1139/f67-052

[65] Ahmad, I., Pacheco, M. and Santos, M. (2006) Oxidative Stress Biomarkers: An in Situ Study of Freshwater Wetland Ecosystem (Pateira de Fermentelos, Portugal). Chemosphere, 65, 952-962. http://dx.doi.org/10.1016/j.chemosphere.2006.03.042

[66] Akcha, F., Izuel, C., Venier, P., Budzinski, H., Burgeot, T. and Narbonne, J.F. (2000) Enzymatic Biomarker Measurement and Study of DNA Adduct Formation in Benzo[a] Pyrene Contaminated Mussels, Mytilus galloprovincialis. Aquatic Toxicology, 49, 269-287. http://dx.doi.org/10.1016/S0166-445X(99)00082-X

[67] Regoli, F., Gorbi, S., Frenzilli, G., Nigro, M., CorsiI, I., Focardi, S. and Winston, G.W. (2002) Oxidative Stress in Ecotoxicology: From the Analysis of Individual Antioxidants to a More Integrated Approach. Marine Environmental Research, 54, 419-423. 
http://dx.doi.org/10.1016/S0141-1136(02)00146-0

[68] Solé, M., Buet, A., Ortiz, L., Maynou, F., Bayona, J.M. and Albaigés, J. (2007) Biochemical Responses in Mussels Exposed to the Water-Accommodated Fraction of the "Prestige" Fuel Oil. Scientia Marina, 71, 373-382. http://dx.doi.org/10.3989/scimar.2007.71n2373

[69] Güll, S., Belge-Kurutas, E., Yildiz, E., Sahan, A. and Doran, F., (2004). "Pollution Correlated Modifications of Liver Antioxidant System and Histopathology of Fish (Cyprinidae) Living in Seyhan Dam Lake, Turkey. Environmental International, 30, 605-609. http://dx.doi.org/10.1016/S0160-4120(03)00059-X

[70] Zhen, Y. and Aili, J. (2011) Evaluation of Oxidative Stress Responses and Neurotoxicity Potential of Methamidophos in Mytilus edulis. Advanced Materials Research, 343-344, 795-801. http://dx.doi.org/10.4028/www.scientific.net/AMR.343-344.795

[71] Kurutas, E.B., Sahan, A. and Altun, T. (2009) Oxidative Stress Biomarkers in Liver and Gill Tissues of Spotted Barb (Capoeta barroisi Lortet, 1894) Living in Theriver Ceyhan, Adana, Turkey. Turkish Journal of Biology, 33, 275-282.

[72] Lesser, M.P. (2010) Survivorship, Oxidative Stress, and DNA Damage of Sea Urchin (Strongylocentrotus droebachiensis) Embryos and Larvae Exposed to Ultraviole Tradiation (290-400 nm) in the Gulf of Maine. Photochemistry and Photobiology, 86, 382-388. http://dx.doi.org/10.1111/j.1751-1097.2009.00671.x

[73] Shahbudin, S., Deny, S., Zakirun, A.M., Haziyamin, T.A., Akbar John, B. and Taher, M. (2011) Antioxidant Properties of Soft Coral Dendronephthya sp. International Journal of Pharmacology, 7, 263-267. http://dx.doi.org/10.3923/ijp.2011.263.267

[74] Ahmad, I., Pacheco, M. and Santos, M.A. (2004) Enzymatic and Non-Enzymatic Antioxidants as an Adaptation to Phagocyte-Induced Damage in Anguilla Anguilla L. Following in Situ Harbor Water Exposure. Ecotoxicology and Environmental Safety, 57, 290-302. http://dx.doi.org/10.1016/S0147-6513(03)00080-0

[75] Santos, M.A., Pacheco, M. and Ahmad, I. (2004) Anguilla Anguilla L. Antioxidants Responses to in Situ Bleached Kraft Pulp Mill Effluent Outlet Exposure. Environmental International, 30, 301-308. http://dx.doi.org/10.1016/S0160-4120(03)00178-8

[76] Ahmad, I., Oliveira, M., Pacheco, M.M, and Santos, M.A. (2005) Anguilla Anguilla L. Oxidative Stress Biomarkers Responses to Copper Exposure with or without $\beta$-naphthoflavone Pre-Exposure. Chemosphere, 61, 267-275. http://dx.doi.org/10.1016/j.chemosphere.2005.01.069

[77] Havelkova, M., Blahova, J., Kroupova, H., Randak, T., Leontovycova, I., Grabic, R., Pospisil, R. and Svobodova, Z. (2008) Biomarkers of Contaminant Exposure in Chub (Leuciscuscephalus L.)-Biomonitoring of Major Rivers in the Czech Republic. Sensors, 8, 2589-2603. http://dx.doi.org/10.3390/s8042589

[78] Siroka, Z., Krijt, J., Randak, T., Svobodova, Z., Peskova, G., Fuksa, J., Hajslova, J., Jarkovsky, J. and Janska, M. (2005) Organic Pollutant Contamination of the River Elbe as Assessed by Biochemical Markers. Acta Veterinaria Brno, 74, 293-303. http://dx.doi.org/10.2754/avb200574020293

[79] Rathod, V. and Balkrishna, P.A. (2011) Lipid Peroxide, Glutathione and Glutathione-Dependent Enzyme (GST) in Mixed Zooplankton from the North-West Coast of India: Implication for the Use of Environmental Monitoring. African Journal of Biotechnology, 10, 7862-7867. http://dx.doi.org/10.5897/AJB10.1909

[80] Havelková, M., Randák, T., Blahová, J. and Slatinská, I. (2010) Biochemical Markers for the Assessment of Aquatic Environment Contamination. Interdisciplinary Toxicology, 1, 169181. 
[81] Pandey, S., Parvez, S., Sayeed, I., Haque, R., Bin-Hafeez, B. and Raisuddin, S. (2003) Biomarkers of Oxidative Stress: A Comparative Study of River Yamuna Fish Wallago attu (Bl. \& Schn.). Science of the Total Environment, 309, 105-115.

http://dx.doi.org/10.1016/S0048-9697(03)00006-8

[82] Farombi, E., Adelowo, O. and Ajimoko, Y. (2007) Biomarkers of Oxidative Stress and Heavy Metal Levels as Indicators of Environmental Pollution in African Cat Fish (Clarias gariepinus) from Nigeria Ogun River. International Journal Environmental Research Public Health, 4, 158-165. http://dx.doi.org/10.3390/ijerph2007040011

[83] Mohamed, F.A. (2001) Impacts of Environmental Pollution in the Southern Region of Lake Manzalah, Egypt, on the Histological Structures of the Liver and Intestine of Oreochromis niloticus and Tilapia zillii. Journal of Egyptian Academy Society for Environmental Development, 2, 25-42.

[84] Ptashynski, M., Pedlar, R., Evan, R., Baron, C. and Klaver, J. (2002) Toxicology of Dietary Nickel in Lake White Fish (Coregonus clupeaformis). Aquatic Toxicology, 58, 229-247. http://dx.doi.org/10.1016/S0166-445X(01)00239-9

[85] Tripathi, C.L. and Shukla, S.P. (1990) Enzymatic and Ultrastructural Studies in a Freshwater Catfish: Impact of Methyl Parathion. Biomedical Environmental Science, 3, 166-182.

Submit or recommend next manuscript to SCIRP and we will provide best service for you:

Accepting pre-submission inquiries through Email, Facebook, LinkedIn, Twitter, etc. A wide selection of journals (inclusive of 9 subjects, more than 200 journals)

Providing 24-hour high-quality service

User-friendly online submission system

Fair and swift peer-review system

Efficient typesetting and proofreading procedure

Display of the result of downloads and visits, as well as the number of cited articles Maximum dissemination of your research work

Submit your manuscript at: http://papersubmission.scirp.org/

Or contact jep@scirp.org 